\title{
Omega-3 fatty acid supplementation can improve both symptoms and signs of dry eye disease
}

This article was published in the following Dove Press journal:

Clinical Interventions in Aging

3 March 2017

Number of times this article has been viewed

Jae-Woo Kwon'

Sang Beom Han²

'Department of Internal Medicine, ${ }^{2}$ Department of Ophthalmology, Kangwon National University Hospital, Kangwon National University Graduate School of Medicine, Chuncheon, South Korea
Correspondence: Sang Beom Han Department of Ophthalmology, Kangwon National University Hospital, 156

Baengnyeong-ro, Chuncheon, Kangwon 200-722, South Korea

Tel +82332589210

Fax +82 332582296

Email m.sangbeom.han@gmail.com

\section{Dear editor}

We read with great interest the article by Gatell-Tortajada ${ }^{1}$ entitled "Oral supplementation with a nutraceutical formulation containing omega-3 fatty acids, vitamins, minerals, and antioxidants in a large series of patients with dry eye symptoms: results of a prospective study". The prospective large-scale study was undoubtedly well designed and conducted, and the authors should be congratulated for successfully demonstrating that oral omega-3 fatty acid supplementation can be an effective treatment for dry eye symptoms. ${ }^{1}$

The authors showed that supplementation of omega- 3 fatty acids improved dry eye signs, such as corneal erosion, tear film breakup time, and conjunctival hyperemia, suggesting that they can reduce ocular surface inflammation and also alleviate dry eye symptoms. ${ }^{1}$ Rashid et $\mathrm{al}^{2}$ also demonstrated that topical application of omega-3 fatty acids led to a decrease in dry eye signs and inflammatory changes at both cellular and molecular levels.

We would like to point out that the supplementation of omega-3 fatty acids can also affect the perception of the pain and discomfort caused by dry eye. Galor et $\mathrm{al}^{3}$ recently showed that dry eye symptoms were more closely associated with nonocular pain, depression, and post-traumatic stress disorder than tear film parameters. Increased omega-6:omega-3 ratio in the diet was also suggested to be an important cause of the increased incidence of both dry eye disease and major depression. ${ }^{2,4} \mathrm{~A}$ recent study using an animal model revealed that omega-3 fatty acid supplementation improved depressive-like behaviors and also alleviated neural apoptosis. ${ }^{5} \mathrm{~A}$ number of studies suggested that omega-3 fatty acids might have a potential clinical value in the prevention and treatment of psychopathologies, including stress, anxiety, and depression. ${ }^{4,5}$ Therefore, it can be assumed that omega-3 fatty acids might improve the mood and psychological stress of the patients and affect the perception of the discomfort and pain caused by dry eye disease, which can also contribute to the improvement of dry eye symptoms.

We believe that further studies including the evaluation of the psychological parameters would be helpful for the elucidation of the effect of omega- 3 fatty acid supplementation.

\section{Disclosure}

The authors report no conflicts of interest in this communication. 


\section{References}

1. Gatell-Tortajada J. Oral supplementation with a nutraceutical formulation containing omega-3 fatty acids, vitamins, minerals, and antioxidants in a large series of patients with dry eye symptoms: results of a prospective study. Clin Interv Aging. 2016;11:571-578.

2. Rashid S, Jin Y, Ecoiffier T, Barabino S, Schaumberg DA, Dana MR. Topical omega-3 and omega- 6 fatty acids for treatment of dry eye. Arch Ophthalmol. 2008;126(2):219-225.

3. Galor A, Felix ER, Feuer W, et al. Dry eye symptoms align more closely to non-ocular conditions than to tear film parameters. Br J Ophthalmol. 2015;99(8):1126-1129.
4. Kiecolt-Glaser JK, Belury MA, Porter K, Beversdorf DQ, Lemeshow S, Glaser R. Depressive symptoms, omega-6:omega-3 fatty acids, and inflammation in older adults. Psychosom Med. 2007;69(3):217-224.

5. Wu YQ, Dang RL, Tang MM, et al. Long chain omega-3 polyunsaturated fatty acid supplementation alleviates doxorubicin-induced depressivelike behaviors and neurotoxicity in rats: involvement of oxidative stress and neuroinflammation. Nutrients. 2016;8(4):243.

Dove Medical Press encourages responsible, free and frank academic debate. The content of the Clinical Interventions in Aging 'letters to the editor' section does not necessarily represent the views of Dove Medical Press, its officers, agents, employees, related entities or the Clinical Interventions in Aging editors. While all reasonable steps have been taken to confirm the content of each letter, Dove Medical Press accepts no liability in respect of the content of any letter, nor is it responsible for the content and accuracy of any letter to the editor.

\section{Publish your work in this journal}

Clinical Interventions in Aging is an international, peer-reviewed journal focusing on evidence-based reports on the value or lack thereof of treatments intended to prevent or delay the onset of maladaptive correlates of aging in human beings. This journal is indexed on PubMed Central, MedLine,
CAS, Scopus and the Elsevier Bibliographic databases. The manuscript management system is completely online and includes a very quick and fair peer-review system, which is all easy to use. Visit http://www.dovepress. com/testimonials.php to read real quotes from published authors. 